\title{
KINERJA DAN NILAI TAMBAH AGROINDUSTRI SAGU AREN DI KABUPATEN LAMPUNG SELATAN
}

\author{
(Performance and Added Value of Sago Aren Agroindustry in Lampung Selatan Regency)
}

\author{
Abu Haris Husain, Ktut Murniati, Adia Nugraha \\ Jurusan Agribisnis, Fakultas Pertanian, Universitas Lampung, Jl. Prof. Dr. Soemantri Brojonegoro No.1 \\ Bandar Lampung 35145, E-mail: ktut.murniati@fp.unila.ac.id
}

\begin{abstract}
This study aimed to analyze the raw material procurement system based on six components, the performance and the added value of the palm sago agro-industry in Natar subdistrict of South Lampung Regency. The research was a case study in which location was chosen purposively in four Sago Aren Agroindustries by considerating that there were only four agro-industries that were still actively producing sugar palm sago in that area. The reseach data collection was conducted in March - April 2018 and analyzed by qualitative and quantitative descriptive and added value analysis. The results showed that the six components of raw material procurement namely time, place, quality, organization, quantity, and price in Sago Aren of Adi Putra, Oblak, and Surahmat Agroindustries were appropriate because they have been in line with expectations. There was still a component of material procurement standards that have not been matched or did not in line with the expectation in Kartim Agroindustry namely quantity. Production performance in the Sago Aren Agroindustries could be classified as good, because four of the five indicators in production performance namely productivity, capacity, quality, and speed of delivery were appropriate, while indicators of flexibility in the four sago palm agroindustry was not optimal, and the four sago palm agroindustry was feasible because it provided positive added value.
\end{abstract}

Key words: sagu aren, performance, value added

\section{PENDAHULUAN}

Indonesia merupakan negara yang memiliki sumberdaya alam yang melimpah mulai dari pertanian, kehutanan, perikanan, dan pertambangan. Sumberdaya alam tersebut berkontribusi terhadap Produk Domestik Bruto (PDB) dan memberikan peran yang cukup besar dalam perekonomian secara keseluruhan. Pertanian merupakan sumber mata pencaharian utama penduduk Indonesia sehingga sektor pertanian dapat menjadi motor penggerak dalam meningkatkan pendapatan masyarakat dan menciptakan kesempatan kerja. Dengan demikian, perekonomian Indonesia sangat bertumpu pada perkembangan sektor pertanian.

Provinsi Lampung merupakan salah satu provinsi di Indonesia yang perekonomiannya juga bertumpu pada sektor pertanian. Hal ini dapat dilihat dari kontribusi terbesar (PDRB) Provinsi lampung yang berasal dari kategori pertanian, kehutanan, dan perikanan. Provinsi Lampung merupakan wilayah yang memiliki aneka ragam produksi tanaman perkebunan salah satunya ialah tanaman aren. Tanaman aren dinilai sebagai salah satu komoditas pertanian yang cukup strategis dalam mendukung pengembangan perekonomian.
BPS (2014) menunjukkan bahwa dari total luas areal tanaman aren di Provinsi Lampung tahun 2014, sebesar 32,08\% masih belum menghasilkan aren, 55\% sudah menghasilkan aren, sedangkan sisanya sebesar $12,92 \%$ tidak menghasilkan aren. Hal ini menunjukkan bahwa masih ada areal tanaman aren yang belum dikelola secara optimal sehingga produksi aren tergolong rendah dibandingkan dengan komoditas perkebunan yang lain. Produksi aren yang kurang optimal menyebabkan ketersediaan aren di Provinsi Lampung minim. Namun, beberapa industri di Provinsi Lampung mampu memanfaatkan aren menjadi produk olahan lain, salah satunya adalah sagu aren.

Sagu aren merupakan salah satu produk olahan aren yang diperoleh dari proses penggilingan batang aren untuk diambil saripatinya lalu diendapkan menjadi sagu. Menurut Dinas Perindustrian Kabupaten Lampung Selatan (2014), terdapat empat Agroindustri Sagu Aren di Kabupaten Lampung Selatan yang masih aktif dalam memproduksi sagu aren. Berdasarkan keempat pengolahan sagu aren tersebut, terdapat tiga pengolahan sagu aren yang produksi riilnya mengalami kesenjangan dengan kapasitas yang dapat diproduksi. 
Kesenjangan produksi ini dapat disebabkan oleh berbagai macam masalah, seperti bahan baku yang sulit diperoleh. Bahan baku yang sulit diperoleh menyebabkan ketidakpastian bagi para pelaku agroindustri sagu aren dalam hal keberlanjutan pengadaan bahan baku. Pengadaan bahan baku merupakan hal yang sangat penting karena menentukan keberhasilan agroindustri sagu aren. Ketersediaan bahan baku yang tepat waktu, tempat, kualitas, kuantitas, organisasi, dan harga akan mempengaruhi kinerja agroindustri sagu aren. Semakin baik kinerja agroindustri, maka semakin besar nilai tambah yang dapat diperoleh. Selanjutnya, peningkatan nilai tambah akan diikuti oleh peningkatan pendapatan dan keuntungan bagi agroindustri sagu aren. Berdasarkan uraian tersebut, maka tujuan penelitian ini adalah menganalisis proses pengadaan bahan baku pada Agroindustri Sagu Aren di Kecamatan Natar Lampung Selatan, menganalisis kinerja produksi agroindustri sagu aren, dan menganalisis nilai tambah agroindustri sagu aren.

\section{METODE PENELITIAN}

Penelitian ini dilaksanakan di Agroindustri Sagu Aren Kecamatan Natar Kabupaten Lampung Selatan dengan menggunakan metode studi kasus. Lokasi ditentukan secara sengaja (purposive) dengan pertimbangan bahwa terdapat beberapa Agroindustri Sagu Aren yang produksi riilnya mengalami kesenjangan dengan kapasitas yang dapat diproduksi. Pengambilan data dilakukan pada bulan Maret - April 2018. Responden dalam penelitian ini adalah keempat pemilik Agroindustri Sagu Aren di Kecamatan Natar Kabupaten Lampung Selatan.

Jenis data yang digunakan dalam penelitian ini adalah data primer dan data sekunder. Data primer diperoleh dari wawancara dan pengamatan langsung. Data sekunder diperoleh dari studi literatur, jurnal ilmiah, penelitian terdahulu, dan pustaka lainnya yang berhubungan dengan penelitian ini, serta lembaga/instansi yang terkait seperti BPS, Dinas Perindustrian Kabupaten Lampung Selatan, dan data internal setiap Agroindustri Sagu Aren di Kecamatan Natar Lampung Selatan.

Metode analisis data yang digunakan pada penelitian ini adalah metode analisis deskriptif kualitatif dan analisis deskriptif kuantitatif. Analisis deskriptif kualitatif digunakan untuk menganalisis tujuan pertama, yaitu bagaimana pengadaan bahan baku berupa pelaksanaan enam tepat pada agroindustri sagu aren. Enam tepat tersebut adalah tepat waktu, tepat tempat, tepat organisasi, tepat kualitas, tepat kuantitas, dan tepat harga.

Analisis deskriptif kuantitatif dan kualitatif digunakan untuk menganalisis tujuan kedua yaitu menganalisis kinerja produksi pada agroindustri sagu aren. Menurut Prasetya dan Lukiastuti (2009), analisis kinerja diukur berdasarkan komponen produktivitas, kapasitas, kualitas, kecepatan pengiriman, dan fleksibilitas.

\section{Produktivitas}

Produktivitas adalah suatu ukuran untuk mengkonversi input dari proses transformasi ke dalam output. Produktivitas dari agroindustri dihitung dari unit yang diproduksi (output) dengan masukan yang digunakan (tenaga kerja) yang dirumuskan sebagai berikut :

Produktivitas $=\frac{\text { Unit yang diproduksi }(\mathrm{kg})}{\text { Masukan yang digunakan }(\mathrm{HOK})}$

\section{Kapasitas}

Kapasitas adalah suatu ukuran yang menyangkut kemampuan output dari suatu proses. Kapasitas agroindustri dapat dirumuskan sebagai berikut:

Capacity Utilization $=\frac{\text { Actual Output }}{\text { Design Input }}$

Menurut Render dan Heizer (2001):

a. Jika kapasitas $>0,5$ atau $50 \%$, maka agroindustri telah berproduksi secara baik.

b. Jika kapasitas $<0,5$ atau $50 \%$, maka agroindustri berproduksi kurang baik.

\section{Kualitas}

Kualitas dari proses pada umumnya diukur dengan tingkat ketidaksesuaian dari produk yang dihasilkan. Mutu sagu aren dapat dinilai dengan menggunakan parameter-parameter baik terhadap sifat yang dapat dilihat maupun bentuk fisik sagu aren seperti warna putih (tidak kuning), kering, tidak berbau, dan tekstur yang baik.

\section{Kecepatan Pengiriman}

Kecepatan pengiriman memiliki dua ukuran dimensi, yaitu jumlah waktu antara produk ketika dipesan untuk dikirimkan ke pelanggan serta ketepatan waktu dalam pengiriman. 


\section{Fleksibilitas}

Fleksibel digunakan untuk mengukur bagaimana proses transformasi menjadi lebih baik. Ada tiga dimensi dari fleksibel, pertama kecepatan proses transformasi batang aren menjadi sagu aren. Ke dua adalah kemampuan bereaksi untuk berubah dalam volume. Ke tiga adalah kemampuan dari proses produksi yang lebih dari satu produk.

Analisis deskriptif kuantitatif digunakan untuk menganalisis tujuan ketiga, yaitu untuk menghitung besarnya nilai tambah batang aren yang diolah menjadi sagu aren. Analisis ini menggunakan metode Hayami (1987) dengan kriteria sebagai berikut:

a. Jika NT $>0$, berarti agroindustri sagu aren memberikan nilai tambah (positif).

b. Jika NT $<0$, berarti agroindustri sagu aren memberikan nilai tambah (negatif).

\section{HASIL DAN PEMBAHASAN}

\section{Karakteristik Responden}

Responden dalam penelitian ini adalah pemilik agroindustri sagu aren di Kecamatan Natar Kabupaten Lampung Selatan. Keempat agroindustri tersebut adalah Agroindustri Adi Putra, Agroindustri Oblak, Agroindustri Surahmat, dan Agroindustri Kartim. Umur pemilik agroindustri berkisar antara 50-60 tahun dengan pendidikan terakhir yang masih tergolong rendah yaitu SD dan SMA. Jumlah tanggungan keluarga responden berkisar antara 4-6 orang. Pengalaman usaha responden berkisar antara 17-30 tahun sehingga dapat dikatakan keempat responden sudah cukup berpengalaman. Modal awal yang dibutuhkan keempat sagu aren cukup besar berkisar antara Rp150.000.000,00Rp350.000.000,00.

Tabel 1. Pengadaan bahan baku Agroindustri Sagu Aren di Lampung Selatan

\begin{tabular}{|c|c|c|c|c|c|c|c|c|}
\hline \multirow{2}{*}{$\begin{array}{c}\text { Komponen } \\
\text { Pengadaan } \\
\text { Bahan Baku }\end{array}$} & \multicolumn{2}{|c|}{ Agroindustri Adi Putra } & \multicolumn{2}{|c|}{ Agroindustri Oblak } & \multicolumn{2}{|c|}{ Agroindustri Surahmat } & \multicolumn{2}{|c|}{ Agroindustri Kartim } \\
\hline & Harapan & Kenyataan & Harapan & Kenyataan & Harapan & Kenyataan & Harapan & Kenyataan \\
\hline Waktu & $\begin{array}{l}\text { Pengadaan } \\
\text { bahan baku } \\
\text { dilakukan } \\
8-10 \text { kali } \\
\text { dalam } \\
\text { sebulan }\end{array}$ & $\begin{array}{l}\text { Pengadaan } \\
\text { bahan baku } \\
\text { dilakukan } 10 \\
\text { kali dalam } \\
\text { sebulan }\end{array}$ & $\begin{array}{l}\text { Pengadaan } \\
\text { bahan baku } \\
\text { dilakukan 9- } \\
10 \text { kali } \\
\text { dalam } \\
\text { sebulan }\end{array}$ & $\begin{array}{l}\text { Pengadaan } \\
\text { bahan baku } \\
\text { dilakukan } 10 \\
\text { kali dalam } \\
\text { sebulan }\end{array}$ & $\begin{array}{l}\text { Pengadaan } \\
\text { bahan baku } \\
\text { dilakukan 9- } \\
10 \text { kali } \\
\text { dalam } \\
\text { sebulan }\end{array}$ & $\begin{array}{l}\text { Pengadaan } \\
\text { bahan baku } \\
\text { dilakukan } 10 \\
\text { kali dalam } \\
\text { sebulan }\end{array}$ & $\begin{array}{l}\text { Pengadaan } \\
\text { bahan baku } \\
\text { dilakukan } \\
8-10 \text { kali } \\
\text { dalam } \\
\text { sebulan }\end{array}$ & $\begin{array}{l}\text { Pengadaan } \\
\text { bahan baku } \\
\text { dilakukan } 9 \\
\text { kali dalam } \\
\text { sebulan }\end{array}$ \\
\hline Tempat & $\begin{array}{l}\text { Lokasi } \\
\text { bahan baku } \\
\text { mudah } \\
\text { dijangkau }\end{array}$ & $\begin{array}{l}\text { Lokasi bahan } \\
\text { baku mudah } \\
\text { dijangkau }\end{array}$ & $\begin{array}{l}\text { Lokasi } \\
\text { bahan baku } \\
\text { mudah } \\
\text { dijangkau }\end{array}$ & $\begin{array}{l}\text { Lokasi } \\
\text { bahan baku } \\
\text { mudah } \\
\text { dijangkau }\end{array}$ & $\begin{array}{l}\text { Lokasi } \\
\text { bahan baku } \\
\text { mudah } \\
\text { dijangkau }\end{array}$ & $\begin{array}{l}\text { Lokasi } \\
\text { bahan baku } \\
\text { mudah } \\
\text { dijangkau }\end{array}$ & $\begin{array}{l}\text { Lokasi } \\
\text { bahan baku } \\
\text { mudah } \\
\text { dijangkau }\end{array}$ & $\begin{array}{l}\text { Lokasi } \\
\text { bahan } \\
\text { baku } \\
\text { mudah } \\
\text { dijangkau }\end{array}$ \\
\hline Kualitas & $\begin{array}{l}\text { Batang } \\
\text { aren yang } \\
\text { digunakan } \\
\text { berkualitas } \\
\text { baik, yaitu } \\
\text { batang } \\
\text { tidak } \\
\text { diambil } \\
\text { niranya } \\
\text { serta tidak } \\
\text { rusak. }\end{array}$ & $\begin{array}{l}\text { Batang aren } \\
\text { berkualitas } \\
\text { baik, yaitu } \\
\text { batang tidak } \\
\text { diambil } \\
\text { niranya serta } \\
\text { tidak rusak } \\
\text { atau busuk }\end{array}$ & $\begin{array}{l}\text { Batang aren } \\
\text { yang } \\
\text { digunakan } \\
\text { berkualitas } \\
\text { baik yaitu } \\
\text { batang tidak } \\
\text { diambil } \\
\text { niranya, } \\
\text { berumur } 10 \\
\text { tahun, serta } \\
\text { tidak rusak. }\end{array}$ & $\begin{array}{l}\text { Batang aren } \\
\text { berkualitas } \\
\text { baik yaitu } \\
\text { batang tidak } \\
\text { diambil } \\
\text { niranya, } \\
\text { batang } \\
\text { berumur } \\
\pm 10 \text { tahun, } \\
\text { serta tidak } \\
\text { rusak. }\end{array}$ & $\begin{array}{l}\text { Batang aren } \\
\text { yang } \\
\text { digunakan } \\
\text { berkualitas } \\
\text { baik, yaitu } \\
\text { batang tidak } \\
\text { diambil } \\
\text { niranya, } \\
\text { sudah } \\
\text { terdapat } \\
\text { buah aren. }\end{array}$ & $\begin{array}{l}\text { Batang aren } \\
\text { berkualitas } \\
\text { baik, yaitu } \\
\text { batang tidak } \\
\text { diambil } \\
\text { niranya } \\
\text { serta tidak } \\
\text { rusak atau } \\
\text { busuk }\end{array}$ & $\begin{array}{l}\text { Batang aren } \\
\text { berkualitas } \\
\text { baik, yaitu } \\
\text { batang } \\
\text { tidak } \\
\text { diambil } \\
\text { niranya } \\
\text { serta tidak } \\
\text { rusak atau } \\
\text { busuk }\end{array}$ & $\begin{array}{l}\text { Batang aren } \\
\text { berkualitas } \\
\text { baik, yaitu } \\
\text { batang } \\
\text { tidak } \\
\text { diambil } \\
\text { niranya } \\
\text { serta tidak } \\
\text { rusak atau } \\
\text { busuk }\end{array}$ \\
\hline Organisasi & $\begin{array}{l}\text { Adanya } \\
\text { pemasok } \\
\text { bahan baku } \\
\text { batang aren }\end{array}$ & $\begin{array}{l}\text { Terdapat } \\
\text { pemasok dari } \\
\text { berbagai } \\
\text { daerah }\end{array}$ & $\begin{array}{l}\text { Adanya } \\
\text { pemasok } \\
\text { bahan baku } \\
\text { batang aren }\end{array}$ & $\begin{array}{l}\text { Terdapat } \\
\text { pemasok dari } \\
\text { berbagai } \\
\text { daerah }\end{array}$ & $\begin{array}{l}\text { Adanya } \\
\text { pemasok } \\
\text { bahan baku } \\
\text { batang aren }\end{array}$ & $\begin{array}{l}\text { Terdapat } \\
\text { pemasok dari } \\
\text { berbagai } \\
\text { daerah }\end{array}$ & $\begin{array}{l}\text { Adanya } \\
\text { pemasok } \\
\text { bahan baku } \\
\text { batang aren }\end{array}$ & $\begin{array}{l}\text { Terdapat } \\
\text { pemasok } \\
\text { dari } \\
\text { berbagai } \\
\text { daerah }\end{array}$ \\
\hline Kuantitas & $\begin{array}{l}\text { Bahan } \\
\text { baku } \\
\text { tersedia } \\
10.000 \mathrm{~kg} / \\
\text { produksi }\end{array}$ & $\begin{array}{l}\text { Bahan baku } \\
\text { tersedia rata- } \\
\text { rata } 10.084 \\
\text { kg/produksi }\end{array}$ & $\begin{array}{l}\text { Bahan baku } \\
\text { tersedia } \\
10.000 \mathrm{~kg} \\
\text { /produksi }\end{array}$ & $\begin{array}{l}\text { Bahan baku } \\
\text { tersedia } \\
\text { rata-rata } \\
10.017 \\
\mathrm{~kg} / \text { produksi }\end{array}$ & $\begin{array}{l}\text { Bahan baku } \\
\text { tersedia } \\
10.000 \mathrm{~kg} \\
\text { /produksi }\end{array}$ & $\begin{array}{l}\text { Bahan baku } \\
\text { tersedia } \\
\text { rata-rata } \\
10.073 \\
\mathrm{~kg} / \text { produksi }\end{array}$ & $\begin{array}{l}\begin{array}{l}\text { Bahan } \\
\text { baku } \\
\text { tersedia } \\
10.000 \mathrm{~kg} / \\
\text { produksi }\end{array} \\
\end{array}$ & $\begin{array}{l}\text { Bahan baku } \\
\text { tersedia } \\
\text { rata-rata } \\
9.363 \mathrm{~kg} \\
\text { /produksi }\end{array}$ \\
\hline Harga & $\begin{array}{l}\text { Harga batang } \\
\text { aren sebesar } \\
\text { Rp580- } \\
\text { Rp600/kg }\end{array}$ & $\begin{array}{l}\text { Harga batang } \\
\text { aren sebesar } \\
\text { Rp600/kg }\end{array}$ & $\begin{array}{l}\text { Harga batang } \\
\text { aren sebesar } \\
\text { Rp600- } \\
\text { Rp650/kg }\end{array}$ & $\begin{array}{l}\text { Harga } \\
\text { batang aren } \\
\text { sebesar } \\
\text { Rp650/kg }\end{array}$ & $\begin{array}{l}\text { Harga batang } \\
\text { aren sebesar } \\
\text { Rp650- } \\
\text { Rp670/kg }\end{array}$ & $\begin{array}{l}\text { Harga } \\
\text { batang aren } \\
\text { sebesar } \\
\text { Rp660/kg }\end{array}$ & $\begin{array}{l}\text { Harga } \\
\text { batang aren } \\
\text { sebesar } \\
\text { Rp600/kg }\end{array}$ & $\begin{array}{l}\text { Harga } \\
\text { batang aren } \\
\text { sebesar } \\
\text { Rp600/kg }\end{array}$ \\
\hline
\end{tabular}




\section{Pengadaan Bahan Baku Batang Aren}

Bahan baku dalam penelitian ini berupa batang aren yang digunakan untuk produksi sagu aren. Pengadaan bahan baku dapat dilihat pada Tabel 1 . Berdasarkan kegiatan pengadaan bahan baku pada Tabel 1 dapat diketahui bahwa seluruh komponen pengadaan bahan baku berupa waktu, tempat, kualitas, organisasi, kuantitas, dan harga pada Agroindustri Adi Putra sudah tepat karena kegiatan pengadaan bahan baku yang diharapkan oleh pihak Agroindustri Adi Putra sudah sesuai dengan realita yang terjadi. Hal ini juga terdapat pada kegiatan pengadaan bahan baku di Agroindustri Surahmat dan Agroindustri Oblak bahwa seluruh komponen pengadaan bahan baku yang diharapkan oleh pihak Agroindustri sudah sesuai dengan realita yang terjadi.

Berbeda halnya dengan Agroindustri Kartim, terdapat salah satu komponen pengadaan bahan baku yaitu kuantitas belum tepat karena kuantitas bahan baku yang diharapkan oleh pihak agroindustri belum sesuai dengan realita yang ada. Akan tetapi, lima komponen pengadaan bahan baku lainnya yaitu waktu, tempat, kualitas, organisasi, dan harga pada Agroindustri Kartim sudah tepat. Hasil penelitian ini sejalan dengan penelitian Aldhariana, Lestari, dan Ismono (2016) yang menyebutkan bahwa seluruh komponen pengadaan bahan baku pada Agroindustri TS sudah tepat, karena kegiatan pengadaan bahan baku yang diharapkan sudah sesuai dengan realita yang terjadi.

\section{Proses Produksi Sagu Aren}

Sagu aren adalah produk sagu yang diperoleh dari proses penggilingan batang aren untuk diambil saripatinya lalu diendapkan menjadi sagu. Sagu aren dapat dimanfaatkan sebagai bahan baku pembuatan mie soun, kue, bakmie, bakso, dll.. Proses pembuatan atau proses produksi sagu aren merupakan proses pengubahan faktor produksi (input) berupa bahan baku utama batang aren dan bahan penunjang menjadi sebuah produk atau barang (output) berupa sagu aren. Proses produksi sagu aren di keempat agroindustri sagu aren masih tergolong sederhana, karena masih menggunakan tenaga kerja manusia dalam setiap tahapan prosesnya. Pada dasarnya proses pembuatan sagu aren di keempat agroindustri ini melalui tahapan yang sama, antara lain pemotongan batang aren, pemarutan batang aren, pengayakan saripati aren, pencucian sagu aren, penjemuran, dan pengemasan yang dapat dilihat pada Gambar 1.

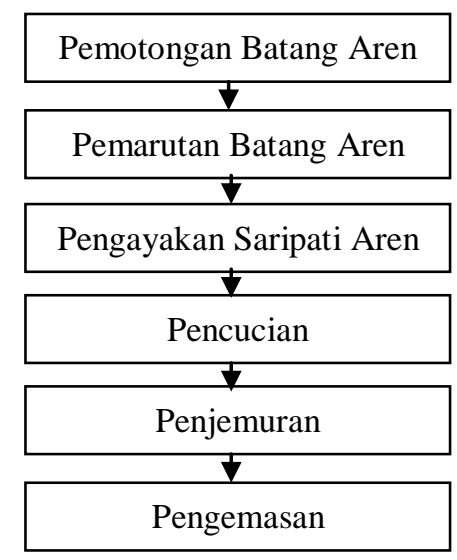

Gambar 1. Proses pembuatan sagu aren

\section{Analisis Kinerja Produksi}

Menurut Prasetya dan Lukiastuti (2009), kinerja produksi dilihat dari aspek produktivitas, kapasitas, kualitas, kecepatan pengiriman, dan fleksibilitas yang terdapat pada agroindustri sagu aren.

\section{Produktivitas Tenaga Kerja}

Produktivitas adalah suatu ukuran untuk mengkonversi input dari proses transformasi ke dalam output. Produktivitas tenaga kerja diperoleh dari pembagian antara jumlah output dengan tenaga kerja yang digunakan dalam satu bulan. Standar nilai produktivitas tenaga kerja menurut Render dan Heizer (2001) adalah 7,2 kg/HOK. Tabel 2 menunjukkan jumlah output dan HOK yang digunakan di setiap agroindustri sagu aren per produksi. Jumlah output dan HOK tersebut akan dikalikan dengan frekuensi produksi dan jumlah hari kerja untuk mengetahui output yang dihasilkan dan tenaga kerja yang digunakan dalam satu bulan. Berdasarkan hasil perhitungan, diketahui pada Tabel 3 bahwa nilai produktivitas keempat agroindustri sagu aren sudah melebihi standar nilai produktivitas tenaga kerja sebesar $\geq 7,2 \mathrm{~kg} / \mathrm{HOK}$ maka produktivitas keempat agroindustri sagu aren sudah dapat dikatakan baik.

Tabel 2. Jumlah output dan HOK pada Agroindustri Sagu Aren di Lampung Selatan per produksi

\begin{tabular}{lcrcc}
\hline Agroindustri & $\begin{array}{c}\text { Output/ } \\
\text { Produksi } \\
(\mathrm{kg})\end{array}$ & $\begin{array}{c}\text { Frekuensi/ } \\
\text { Bulan } \\
\text { (produksi) }\end{array}$ & $\begin{array}{c}\text { Total } \\
\text { HOK/ } \\
\text { Produksi }\end{array}$ & $\begin{array}{c}\text { Jumlah } \\
\text { Hari } \\
\text { Kerja/ } \\
\text { Bulan }\end{array}$ \\
\hline Oblok & $6.620,00$ & 10,00 & 46,71 & 23 \\
Surahmat & $4.405,00$ & 10,00 & 33,29 & 23 \\
Adi Putra & $2.300,00$ & 10,00 & 16,64 & 25 \\
Kartim & $2.061,11$ & 9,00 & 16,64 & 22 \\
\hline
\end{tabular}


Tabel 3. Produktivitas pada Agroindustri Sagu Aren di Lampung Selatan

\begin{tabular}{lrrc}
\hline $\begin{array}{c}\text { Agroindustri } \\
\text { Sagu Aren }\end{array}$ & $\begin{array}{c}\text { Output/ } \\
\text { Bulan (kg) }\end{array}$ & $\begin{array}{c}\text { Tenaga } \\
\text { Kerja } \\
\text { (HOK/ } \\
\text { bulan) }\end{array}$ & $\begin{array}{c}\text { Produktivitas } \\
\text { (kg/HOK) }\end{array}$ \\
\hline Oblak & $64.000,00$ & $1.074,43$ & 59,57 \\
Surahmat & $44.050,00$ & 765,57 & 57,54 \\
Adi Putra & $23.000,00$ & 416,07 & 55,28 \\
Kartim & $18.550,00$ & 366,71 & 50,66 \\
\hline
\end{tabular}

Tabel 3 menunjukkan bahwa Agroindustri Oblak memiliki produktivitas tenaga kerja tertinggi. Hal itu karena Agroindustri Oblak memiliki tiga mesin pengolahan sehingga output yang dihasilkan lebih banyak dibandingkan ketiga agroindustri lainnya. Hal ini sejalan dengan penelitian Sari, Zakaria, dan Affandi (2015) mengenai kinerja agroindustri emping melinjo yang menyebutkan bahwa produktivitas tenaga kerja agroindustri emping melinjo di Kelurahan Rajabasa sebesar 7,29 $\mathrm{kg} / \mathrm{HOK}$ dan produktivitas untuk agroindustri emping melinjo di Kelurahan Suka Maju sebesar $7,24 \mathrm{~kg} / \mathrm{HOK}$. Artinya, setiap satu HOK mampu memproduksi sebesar 7,29 $\mathrm{kg}$ dan 7,24 kg emping melinjo.

\section{Kapasitas}

Kapasitas merupakan suatu ukuran yang menyangkut kemampuan untuk memproses bahan baku dalam menghasilkan produk sagu aren per satuan waktu. Render dan Heizer (2001) menyebutkan bahwa jika kapasitas $\geq 0,5$ atau 50\%, maka agroindustri telah berproduksi secara baik. Berdasarkan hasil perhitungan yang telah dilakukan, diketahui pada Tabel 4 nilai kapasitas keempat agroindustri sagu aren sudah melebihi standar nilai kapasitas sebesar $\geq 0,5$ atau $50 \%$, maka kapasitas keempat agroindustri sagu aren sudah dapat dikatakan baik.

Tabel 4 menunjukkan bahwa Agroindustri Surahmat dan Adi Putra memiliki nilai kapasitas tertinggi karena output yang dihasilkan lebih mampu mencapai output maksimal dibandingkan kedua agroindustri lainnya. Agroindustri Oblak memiliki output tertinggi, tetapi kapasitas yang dihasilkan lebih rendah karena output yang dihasilkan memiliki selisih yang lebih besar terhadap output maksimal. Selain itu, Agroindustri Kartim memiliki nilai kapasitas yang rendah karena hanya melakukan sembilan kali periode produksi dalam satu bulan, sedangkan ketiga agroindustri lainnya melakukan sepuluh kali periode produksi dalam satu bulan.
Tabel 4. Kapasitas pada Agroindustri Sagu Aren di Lampung Selatan

\begin{tabular}{lccc}
\hline $\begin{array}{c}\text { Agroindustri } \\
\text { Sagu Aren }\end{array}$ & $\begin{array}{c}\text { Output/ } \\
\text { Bulan }(\mathrm{kg})\end{array}$ & $\begin{array}{c}\text { Output } \\
\text { Maks/Bulan } \\
(\mathrm{kg})\end{array}$ & $\begin{array}{c}\text { Kapasitas } \\
(\mathrm{kg} / \mathrm{HOK})\end{array}$ \\
\hline Surahmat & $44.050,00$ & $52.000,00$ & 0,85 \\
Adi Putra & $23.000,00$ & $27.000,00$ & 0,85 \\
Oblak & $64.000,00$ & $81.000,00$ & 0,79 \\
Kartim & $18.550,00$ & $23.400,00$ & 0,79 \\
\hline
\end{tabular}

Hasil penelitian ini sejalan dengan penelitian Sagala, Affandi, dan Ibnu (2013) yang menyatakan bahwa nilai rata-rata kapasitas agroindustri kelanting adalah sebesar 0,92 atau 92\%. Hal ini berarti agroindustri kelanting sudah berproduksi dengan baik karena nilai kapasitas yang didapat $\geq$ 0,50 atau $50 \%$.

\section{Kualitas}

Kualitas bahan baku sangat menentukan kualitas produk yang dihasilkan. Kualitas batang aren yang baik dapat dilihat dari batang yang tidak disadap atau diambil niranya, berukuran sedang hingga besar, batang aren tidak rusak dan busuk. Produk sagu aren yang berkualitas baik memiliki indikator sagu aren yang berwarna putih, tidak berbau, tekstur baik dan kering. Sagu aren dengan mutu yang lebih rendah mempunyai ciri berwarna kuning, bau tidak normal, dan sedikit lembab. Berdasarkan hasil penelitian, diketahui bahwa sagu aren yang dihasilkan keempat agroindustri sudah berkualitas baik.

\section{Kecepatan Pengiriman}

Kecepatan pengiriman ada dua ukuran dimensi, pertama jumlah waktu antara produk ketika dipesan untuk dikirimkan ke pelanggan, ke dua adalah ketepatan waktu dalam pengiriman. Apabila waktu yang dibutuhkan keempat agroindustri sagu aren kurang atau sama dengan waktu 30 menit dapat menempuh jarak lima kilometer maka dimensi pertama kecepatan pengiriman dikatakan baik.

Keempat agroindustri sagu aren memiliki waktu dan jarak tempuh yang berbeda-beda untuk mengirimkan produknya ke lokasi pasar. Jumlah waktu dan jarak tersebut akan dikonversikan terlebih dahulu dengan standar pengukuran kecepatan pengiriman. Tabel 5 menunjukkan bahwa keempat agroindustri sagu aren sudah dikatakan baik pada dimensi pertama kecepatan pengiriman. 
Tabel 5. Kecepatan pengiriman pada Agroindustri Sagu Aren di Lampung Selatan

\begin{tabular}{|c|c|c|c|c|}
\hline \multirow[b]{2}{*}{$\begin{array}{l}\text { Agroindustri } \\
\text { Sagu Aren }\end{array}$} & \multicolumn{3}{|c|}{ Dimensi Pertama } & Dimensi \\
\hline & $\begin{array}{l}\text { Jumlah } \\
\text { Waktu } \\
\text { (menit) }\end{array}$ & $\begin{array}{c}\text { Jarak } \\
\text { Tempuh } \\
(\mathrm{km})\end{array}$ & $\begin{array}{c}\text { Jarak } \\
\text { Tempuh } \\
\text { Per } 30 \\
\text { Menit } \\
(\mathrm{km})\end{array}$ & $\begin{array}{c}\text { Frekuensi } \\
\text { Pengiriman } \\
\text { Dalam } \\
\text { Satu } \\
\text { Minggu }\end{array}$ \\
\hline Oblak & 60 & 37,6 & 18,80 & 2 \\
\hline Kartim & 20 & 9,5 & 14,25 & 1 \\
\hline Adi Putra & 45 & 20,9 & 13,93 & 1 \\
\hline Surahmat & 50 & 20,9 & 12,54 & 1 \\
\hline
\end{tabular}

Hal ini karena hasil konversi keempat agroindustri menunjukkan bahwa jarak yang ditempuh dalam 30 menit melebihi standar pengukuran yang digunakan. Pada dimensi ke dua kecepatan pengiriman, keempat agroindustri sagu aren juga dikatakan baik karena setiap agroindustri mengirimkan produk minimal satu kali dalam seminggu.

\section{Fleksibilitas}

Fleksibel atau fleksibilitas adalah mengukur bagaimana proses transformasi menjadi lebih baik. Ada tiga dimensi dari fleksibel, pertama bentuk dari fleksibel dilihat dari waktu untuk mendatangkan bahan baku. Waktu yang dibutuhkan dari datangnya bahan baku dan diproses menjadi sagu aren berkisar selama 2-3 hari. Ke dua adalah kemampuan batang aren untuk menghasilkan sagu aren. Dimensi ke dua dikatakan baik jika dengan $10.000 \mathrm{~kg}$ batang aren dapat menghasilkan $\geq 2.150 \mathrm{~kg}$ sagu aren. Dimensi ke tiga adalah kemampuan setiap agroindustri dalam mengubah batang aren menjadi produk selain sagu aren. Tabel 6 menunjukkan bahwa keempat agroindustri sagu aren sudah memiliki fleksibilitas yang baik untuk dimensi pertama dan ke dua. Hal itu disebabkan oleh jumlah yang dibutuhkan setiap agroindustri untuk memproduksi sagu aren adalah 2-3 hari dalam satu kali proses produksi.

Tabel 6. Fleksibilitas pada Agroindustri Sagu Aren di Lampung Selatan

\begin{tabular}{lccc}
\hline Agroindustri & $\begin{array}{c}\text { Jumlah } \\
\text { Waktu } \\
\text { Sagu Aren } \\
\text { Sagu Aren } \\
\text { (hari) }\end{array}$ & $\begin{array}{c}\text { Produksi } \\
\text { Sagu Aren } \\
\text { Dari 10.000 } \\
\text { Kg Bahan } \\
\text { Baku (kg) }\end{array}$ & $\begin{array}{c}\text { Produk } \\
\text { Olahan } \\
\text { Lain Dari } \\
\text { Batang } \\
\text { Aren }\end{array}$ \\
\hline Adi Putra & $2-3$ & 2.280 & Tidak Ada \\
Oblak & $2-3$ & 2.202 & Tidak Ada \\
Kartim & $2-3$ & 2.201 & Tidak Ada \\
Surahmat & $2-3$ & 2.186 & Tidak Ada \\
\hline
\end{tabular}

Pada dimensi ke dua, setiap agroindustri menghasilkan sagu aren lebih dari $2.150 \mathrm{~kg}$ dari $10.000 \mathrm{~kg}$ bahan baku batang aren. Akan tetapi, keempat agroindustri belum dapat menghasilkan produk olahan lain selain sagu aren sehingga dimensi ke tiga pada fleksibilitas belum baik.

Dengan demikian dapat disimpulkan bahwa dari aspek fleksibilitas keempat agroindustri dikatakan belum optimal karena pada dimensi pengukuran ke tiga belum dapat dilakukan. Hal ini sejalan dengan penelitian Sari, Zakaria, dan Affandi (2015) bahwa aspek fleksibilitas agroindustri emping melinjo belum dikatakan baik karena pada tahapan pengukuran ketiga belum dapat dilakukan. Dimensi ke tiga fleksibilitas dapat ditingkatkan dengan cara pengembangan terhadap sumber daya manusia melalui pelatihan untuk dapat menghasilkan produk lain dari batang aren.

\section{Analisis Nilai Tambah Agroindustri Sagu Aren}

Analisis nilai tambah yang dilakukan pada keempat agroindustri sagu aren ini adalah analisis rata-rata dalam kurun waktu satu bulan di saat penelitian yaitu pada bulan Maret. Analisis nilai tambah yang dilakukan pada keempat agroindustri sagu aren dapat dilihat pada Tabel 7. Berdasarkan hasil perhitungan pada Tabel 7 , diketahui bahwa Agroindustri Sagu Aren Oblak paling banyak menggunakan input bahan baku batang aren dibandingkan dengan keempat agroindustri lainnya. Banyaknya batang aren yang digunakan disesuaikan dengan skala produksi keempat agroindustri sagu aren. Perbedaan banyaknya bahan baku yang digunakan akan mempengaruhi banyaknya hasil sagu aren dari kegiatan produksi. Hasil produksi pada Agroindustri Sagu Aren Oblak lebih banyak dibandingkan dengan ketiga agroindustri sagu aren lainnya.

Faktor konversi pada keempat agroindustri memiliki nilai yang sama kecuali Agroindustri Adi Putra. Hasil dari perhitungan Agroindustri Oblak, Surahmat, dan Kartim yaitu sebesar 0,22. Nilai faktor konversi tersebut menyatakan bahwa setiap pengolahan $1 \mathrm{~kg}$ batang aren akan menghasilkan $0,22 \mathrm{~kg}$ sagu aren.

Harga bahan baku batang aren keempat agroindustri berbeda yaitu berkisar antara Rp600,00-Rp660,00 per kg. Perbedaan harga bahan baku disebabkan keempat agroindustri sagu aren memiliki pemasok bahan baku yang berbeda sehingga kesepakatan harga setiap agroindustri berbeda. 
Tabel 7. Nilai tambah sagu aren pada keempat agroindustri di Lampung Selatan bulan Maret 2018

\begin{tabular}{|c|c|c|c|c|c|c|}
\hline \multirow{2}{*}{ No. } & \multirow{2}{*}{ Variabel Output, Input dan Harga } & & \multicolumn{4}{|c|}{ Agroindustri Sagu Aren } \\
\hline & & & Adi Putra & Kartim & Surahmat & Oblak \\
\hline 1. & Output (Kg/produksi) & a & $2.300,00$ & $2.061,11$ & $4.405,00$ & $6.620,00$ \\
\hline 2. & Bahan Baku (Kg/produksi) & $\mathrm{b}$ & $10.084,30$ & $9.362,67$ & $20.146,80$ & $30.050,60$ \\
\hline 3. & Tenaga Kerja (HOK/produksi) & $\mathrm{c}$ & 16,64 & 16,64 & 33,29 & 46,71 \\
\hline 4. & Faktor Konversi & $d=a / b$ & 0,23 & 0,22 & 0,22 & 0,22 \\
\hline 5. & Koefisien Tenaga Kerja & $\mathrm{e}=\mathrm{c} / \mathrm{b}$ & 0,0017 & 0,0018 & 0,0017 & 0,0016 \\
\hline 6. & Harga Output & $\mathrm{f}$ & $6.000,00$ & $6.000,00$ & $6.000,00$ & $5.800,00$ \\
\hline 7. & $\begin{array}{l}\text { Upah Rata-rata Tenaga Kerja } \\
\text { (Rp/HOK) }\end{array}$ & g & $101.277,32$ & $90.682,51$ & $98.892,06$ & $107.512,17$ \\
\hline \multicolumn{7}{|c|}{ Pendapatan dan Keuntungan (Rp/Kg) } \\
\hline 8. & Harga Bahan Baku & $\mathrm{h}$ & 600,00 & 600,00 & 660,00 & 650,00 \\
\hline 9. & Sumbangan Input Lain & $\mathrm{i}$ & 242,09 & 206,06 & 227,21 & 241,76 \\
\hline 10. & Nilai Output & $j=d \times f$ & $1.368,46$ & $1.320,85$ & $1.311,87$ & $1.277,71$ \\
\hline \multirow[t]{2}{*}{11.} & a. Nilai Tambah & $\mathrm{k}=\mathrm{j}-\mathrm{i}-\mathrm{h}$ & 526,38 & 514,79 & 424,26 & 385,95 \\
\hline & b. Rasio Nilai Tambah & $1=(\mathrm{k} / \mathrm{j}) \times 100(\%)$ & 38,46 & 38,97 & 32,37 & 30,21 \\
\hline \multirow[t]{2}{*}{12.} & a. Imbalan Tenaga Kerja & $\mathrm{m}=\mathrm{e} \times \mathrm{g}$ & 167,15 & 161,20 & 163,39 & 167,13 \\
\hline & b. Bagian Tenaga Kerja & $\mathrm{n}=(\mathrm{m} / \mathrm{k}) \mathrm{x} 100(\%)$ & 31,75 & 31,31 & 38,47 & 43,30 \\
\hline \multirow[t]{2}{*}{13.} & a. Keuntungan & $\mathrm{o}=\mathrm{k}-\mathrm{m}$ & 359,23 & 353,59 & 261,28 & 218,82 \\
\hline & b. Tingkat Keuntungan & $\mathrm{p}=\mathrm{o} / \mathrm{k} \times 100(\%)$ & 68,25 & 68,69 & 61,53 & 56,70 \\
\hline \multicolumn{7}{|c|}{ Balas Jasa Pemilik Faktor-faktor Produksi } \\
\hline \multirow{4}{*}{14.} & Marjin Keuntungan & $q=j-h$ & 768,46 & 720,85 & 651,87 & 627,71 \\
\hline & a. Keuntungan & $\mathrm{r}=\mathrm{o} / \mathrm{q} \times 100 \%$ & 46,75 & 49,05 & 40,08 & 34,86 \\
\hline & b. Tenaga Kerja & $\mathrm{s}=\mathrm{m} / \mathrm{q} \times 100 \%$ & 21,75 & 22,36 & 25,06 & 26,63 \\
\hline & c. Input Lain & $\mathrm{t}=\mathrm{i} / \mathrm{q} \times 100 \%$ & 31,50 & 28,59 & 34,85 & 38,51 \\
\hline
\end{tabular}

Kesepakatan harga tersebut dipengaruhi oleh beberapa hal, seperti jarak lokasi bahan baku dan tingkat kesulitan untuk memperoleh bahan baku di wilayah tersebut. Semakin jauh jarak lokasi bahan baku atau semakin sulit pemasok untuk memperoleh bahan baku, maka harga bahan baku semakin tinggi. Selain itu, sumbangan input lain pada keempat agroindustri sagu aren juga berbeda. Sumbangan input lain pada Agroindustri Adi Putra lebih besar dibandingkan dengan keempat agroindustri lainnya yaitu sebesar Rp242,09. Artinya, semakin besar nilai sumbangan input lain maka semakin besar biaya poduksi yang dikeluarkan suatu agroindustri dan begitupula sebaliknya.

Berdasarkan penelitian yang telah dilakukan, diketahui bahwa nilai tambah dari keempat agroindustri sagu aren berkisar antara Rp385,95Rp526,38 per kg. Agroindustri Adi Putra memperoleh nilai tambah lebih besar dibandingkan ketiga agroindustri lainnya karena nilai output pada Agroindustri Adi Putra lebih besar dan harga bahan baku lebih kecil dibandingkan ketiga agroindustri lainnya. Sementara itu, Agroindustri Oblak memiliki nilai tambah paling kecil walaupun produksi yang dihasilkan paling tinggi dibandingkan ketiga agroindustri lainnya. Hal itu dipengaruhi oleh nilai output yang kecil dan harga bahan baku yang tinggi. Rendahnya nilai output tersebut disebabkan oleh penetapan harga jual yang lebih rendah dengan tujuan agar semua produk dapat terjual.

Berdasarkan kriteria nilai tambah, pengembangan keempat agroindustri sagu aren memberikan nilai tambah (positif) karena Nilai Tambah (NT) $>0$. Tabel 7 juga menunjukkan bahwa pengolahan sagu aren telah memberikan nilai tambah terhadap batang aren sebesar 30,21-38,97 persen untuk keempat agroindustri sagu aren. Artinya, untuk setiap Rp100,00 nilai produk akan diperoleh nilai tambah sebesar Rp30,21-Rp38,97. Berdasarkan hasil perhitungan tersebut dapat disimpulkan bahwa keempat Agroindustri Sagu Aren di Kecamatan Natar Lampung Selatan layak untuk dikembangkan.

Hasil penelitian ini sejalan dengan penelitian Aldhariana, Lestari, dan Ismono (2016) mengenai agroindustri beras siger yang menyebutkan bahwa Agroindustri Toga Sari dan Agroindustri Mekar Sari memberikan nilai tambah positif, karena Nilai Tambah $(\mathrm{NT})>0$. Akan tetapi, terdapat perbedaan yaitu pada penelitian Aldhariana, Lestari, dan Ismono (2016) kedua agroindustri beras siger ini termasuk ke dalam agroindustri padat karya karena nilai balas jasa terhadap tenaga kerja lebih besar dibandingkan terhadap nilai keuntungan, sedangkan penelitian ini termasuk ke dalam agroindustri padat modal karena nilai balas jasa terhadap nilai keuntungan lebih besar dibandingkan terhadap nilai tenaga kerja. Oleh 
karena itu, keempat Agroindustri Sagu Aren di Kecamatan Natar Lampung Selatan harus mempunyai modal yang cukup untuk keberlanjutan agroindustri.

Berdasarkan hasil perhitungan, besarnya keuntungan yang diperoleh dari keempat agroindustri sagu aren berkisar antara Rp218,82 Rp359,23 dengan tingkat keuntungan antara 56,7068,69 persen. Keuntungan ini merupakan nilai tambah bersih serta merupakan imbalan bagi agroindustri. Hasil penelitian ini sedikit berbeda dengan penelitian Safitri, Abidin, dan Rosanti (2014) mengenai kinerja dan nilai tambah agroindustri sabut kelapa Kabupaten Pesisir Barat. Hasil penelitian tersebut menunjukkan bahwa keuntungan yang diperoleh sebesar Rp105,04 dengan tingkat keuntungan sebesar 55,06 persen.

\section{KESIMPULAN}

Keenam komponen pengadaan bahan baku yaitu waktu, tempat, kualitas, organisasi, kuantitas, dan harga pada Agroindustri Sagu Aren Adi Putra, Oblak, dan Surahmat sudah tepat karena sudah sesuai dengan harapan, sedangkan pada Agroindustri Kartim masih terdapat satu komponen pengadaan bahan baku yang belum tepat atau belum sesuai dengan harapan yaitu kuantitas. Kinerja produksi pada Agroindustri Sagu Aren Kecamatan Natar Lampung Selatan sudah dapat dikatakan baik, karena empat dari lima indikator dalam kinerja produksi yaitu produktivitas, kapasitas, kualitas, dan kecepatan pengiriman sudah sesuai, sedangkan indikator fleksibilitas pada keempat agroindustri sagu aren belum optimal. Keempat Agroindustri Sagu Aren di Kecamatan Natar Lampung Selatan memberikan nilai tambah positif, sehingga usaha agroindustri layak untuk diusahakan.

\section{DAFTAR PUSTAKA}

Aldhariana SF, Lestari DAH, dan Ismono $\mathrm{H}$. 2016. Keragaan agroindustri beras siger (kasus di Agroindustri Toga Sari Kabupaten Tulang Bawang dan Agroindustri Mekar Sari
Kota Metro). JIIA, 4 (2) : 319-322. http://jurnal.fp.unila.ac.id/index.php/JIA/arti cle/view/1507. [3 Juli 2018].

BPS [Badan Pusat Statistik]. 2014. Luas areal dan produksi tanaman perkebunan rakyat, perkebunan besar negara, perkebunan besar swasta di Provinsi Lampung. https:// lampung.bps.go.id/dynamictable/2017/03/29 /173/luas-areal-dan-produksi-tanaman-perke bunan-rakyat-perkebunan-besar-negara-per kebunan-besar-swasta-di-provinsi-lampung2014.html. [25 Desember 2017].

Dinas Perindustrian Kabupaten Lampung Selatan. 2014. Jumlah Industri/Kegiatan Usaha Kecil Agroindustri Sagu Aren di Lampung Selatan. Dinas Perindustrian Kabupaten Lampung Selatan. Lampung Selatan.

Hayami Y, Toshihiko K, Yoshinori M dan Masdjidin S. 1987. Agricultural Marketing and Processing in Upland Java. A Perspective From A Sunda Village. CGPRT Center. Bogor.

Prasetya H dan Lukiastuti F. 2009. Manajemen Operasi. Media Pressindo. Yogyakarta.

Render B dan Heizer J. 2001. Prinsip-prinsip Manajemen Operasi. PT Salemba Emban Patria. Jakarta.

Safitri Y, Abidin Z, dan Rosanti N. 2014. Kinerja dan nilai tambah agroindustri sabut kelapa pada kawasan usaha agroindustri terpadu (kuat) di Kecamatan Pesisir Selatan Kabupaten Pesisir Barat. JIIA, 2 (2): 166173. http://jurnal.fp.unila.ac.id/index.php/ JIA/article/view/740/68. [3 Juli 2018].

Sagala IC, Affandi MI, dan Ibnu M. 2013. Kinerja usaha agroindustri kelanting di Desa Karang Anyar Kecamatan Gedong Tataan Kabupaten Pesawaran. JIIA, 1 (1) : 60-65. http://jurnal.fp.unila.ac.id/index.php/JIA/arti cle/view/132. [3 Juli 2018].

Sari IRM, Zakaria WA, dan Affandi MI. 2015. Kinerja produksi dan nilai tambah agroindustri emping melinjo di Kota Bandar Lampung. JIIA, 3 (1) : 18-25. http://jurnal.fp.unila.ac.id/index.php/JIA/arti cle/view/1013. [3 Juli 2018]. 